\title{
Myc, Oncogenic Protein Translation, and the Role of Polyamines
}

\author{
Andrea T. Flynn ${ }^{1, *(1)}$ and Michael D. Hogarty ${ }^{1,2}$ \\ 1 Children's Hospital of Philadelphia, Philadelphia, PA 19104, USA \\ 2 Perelman School of Medicine, University of Pennsylvania, Philadelphia, PA 19104, USA; \\ hogartym@email.chop.edu \\ * Correspondence: flynna@email.chop.edu; Tel.: +1-267-425-1920
}

Received: 9 April 2018; Accepted: 22 May 2018; Published: 25 May 2018

check for updates

\begin{abstract}
Deregulated protein synthesis is a common feature of cancer cells, with many oncogenic signaling pathways directly augmenting protein translation to support the biomass needs of proliferating tissues. MYC's ability to drive oncogenesis is a consequence of its essential role as a governor linking cell cycle entry with the requisite increase in protein synthetic capacity, among other biomass needs. To date, direct pharmacologic inhibition of MYC has proven difficult, but targeting oncogenic signaling modules downstream of MYC, such as the protein synthetic machinery, may provide a viable therapeutic strategy. Polyamines are essential cations found in nearly all living organisms that have both direct and indirect roles in the control of protein synthesis. Polyamine metabolism is coordinately regulated by MYC to increase polyamines in proliferative tissues, and this is further augmented in the many cancer cells harboring hyperactivated MYC. In this review, we discuss MYC-driven regulation of polyamines and protein synthetic capacity as a key function of its oncogenic output, and how this dependency may be perturbed through direct pharmacologic targeting of components of the protein synthetic machinery, such as the polyamines themselves, the eukaryotic translation initiation factor $4 \mathrm{~F}(\mathrm{eIF} 4 \mathrm{~F})$ complex, and the eukaryotic translation initiation factor 5A (eIF5A).
\end{abstract}

Keywords: polyamines; MYC; protein synthesis in cancer; neuroblastoma

\section{Introduction}

The polyamines (putrescine, spermidine, and spermine) are small organic cations required in nearly all organisms, from bacteria to mammals, to support cell growth and proliferation [1]. Polyamine abundance is increased in many human cancers, as the polyamine synthetic pathway is a direct downstream target of several oncogenes, including the MYC family [2-5]. The MYC proto-oncogenes (MYC, MYCN, MYCL) have been extensively studied since their discovery in the early 1980's [6] and they continue to be of great interest as the most commonly deregulated genes in human cancer [7]. MYC genes encode highly homologous helix-loop-helix leucine zipper transcription factors, and MYC overexpression correlates with aggressive tumor behavior and poor prognosis in a wide array of cancers [8-12]. MYC plays a central role in creating the biomass necessary to drive cell progression, including significant increases in protein translation. Deregulated protein synthesis is a common feature of human cancers, and recent work has led to a more complete understanding of how qualitative and quantitative alterations in translation control are sentinel to cancer development, maintenance, and progression $[13,14]$.

While MYC oncoproteins provide an attractive target for cancer therapy because of their frequent somatic activation and the addiction that MYC-driven tumors have to these oncoproteins (reviewed in Gabay et al. [15]), they have been difficult to directly inhibit pharmacologically [7,16]. Attempts to 
target MYC using microRNAs or antisense RNAs, or small molecules that interfere with MYC-MAX dimerization, DNA binding or stability are under investigation. Alternatively, therapeutically targeting the principal oncogenic outputs of hyperactivated MYC, such as those driving protein synthesis, may provide an alternative anti-cancer approach. The polyamine synthetic pathway is one such pathway [17]. In this review, we focus on the intersection of MYC-driven translation, the effects of polyamine depletion on protein translation, and the cellular dependencies that exist at this juncture as potential avenues of therapeutic intervention.

\section{MYC-Driven Oncogenesis}

MYC family of proto-oncogenes (MYC, MYCN, MYCL) encode highly homologous transcription factors whose activities are tightly regulated in normal cells but frequently deregulated through translocations, amplifications, or alterations of upstream signaling pathways in approximately half of all human cancers $[7,18]$. MYC genes function at a central node of cellular signaling to link the commitment to enter the cell cycle (stimulated by diverse inputs to MYC) with the requisite biomass production and energetics necessary to do so [19-21]. Indeed, MYC overexpression alone is sufficient to push quiescent cells through the cell cycle [22], while depleting cells of MYC greatly impedes protein translation and markedly reduces proliferation [23]. This non-redundant role in the control of cell proliferation also imbues MYC with significant oncogenic potential when it is deregulated.

Capitalizing on this, many mouse models of cancer have been developed using tissue-specific transgenic overexpression of MYC genes, providing insight into the role of MYC in cancer. Such models include the E $\mu-M Y C$ model of B cell leukemia/lymphoma, the TH-MYCN model of neuroblastoma, the Lo-MYC and Hi-MYC models of prostate cancer, and the involucrin-c-mycER skin cancer model [24-27]. These and other models provide important tools to dissect the molecular mechanisms by which MYC overexpression drives oncogenesis within a tissue and a platform for identifying cooperating lesions and testing therapeutic agents for the prevention or treatment of these malignancies.

\section{MYC and Protein Synthesis}

MYC is a promiscuous transcription factor regulating thousands of target genes through both canonical target gene promoter binding and accumulation at promoters of actively transcribed genes, leading to transcriptional amplification [28-31]. Yet, much of MYC's output supports biomass production. Since $55-75 \%$ of the dry biomass of a cell is protein or involved in protein processing [32], much of MYC's output involves the regulation of genes that support translation: ribosomal proteins, rRNAs, tRNAs, and initiation and elongation factors [21]. Transcriptome analyses in cells in which MYC expression was modulated from null through supraphysiological [33] and in diverse cell types [34] confirm MYC's primordial function in regulating ribosome biogenesis and protein synthesis. This enrichment in the regulation of ribosomal proteins and rRNA, along with genes involved in protein synthesis and turnover, has been similarly shown for MYC-driven cancers such as neuroblastoma $[35,36]$. Genome-wide, MYC binding at the promoters of genes involved in ribosome biogenesis or protein synthesis accounts for roughly the same number of binding events observed for genes involved in cell cycle progression, highlighting the importance of proteogenesis in MYC-driven oncogenesis [37].

Protein processing not only features prominently downstream of MYC signaling, but also leads to a MYC dependency in MYC cancers, as supported by multiple lines of evidence. In switchable models of MYC-induced lymphoma and osteosarcoma, the ability of MYC to induce ribosomal gene products and enhance protein translation correlates with its ability to sustain tumorigenesis [38]. This has been studied in the E $\mu-M Y C$ lymphoma model, where MYC dramatically increases global protein synthesis, cell size, cell cycle entry, and lymphomatous transformation [39]. Intercrossing E $\mu-M Y C$ mice into an L24 ribosomal protein hemizygous background (RPL24+/-) blocked MYC's effects on protein translation and cell size, induced cell cycle entry, and initiated transformation (and increased cell death among MYC-activated lymphoid cells) [39]. Specifically, cap-dependent 
protein translation was enhanced by deregulated MYC, which persisted through mitosis rather than switching to internal ribosome entry site (IRES)-dependent translation [40]. This coordinated switch normally allows a subset of IRES-dependent mitosis-specific proteins to be translated, and their loss downstream of activated MYC may contribute to genomic instability. This switch was restored in the RPL24+ / - background or through treatment of $E \mu-M Y C$ cells with mTOR inhibitors that impair cap-dependent translation. This same RPL24 haploinsuffient restriction of protein synthesis did not impact oncogenesis in TP53 null mice, supporting it as an attribute of MYC oncogenic signaling [39].

Cap-dependent translation initiation is rate-limiting for most translated proteins and is stimulated by the eukaryotic translation initiation 4F (eIF4F) complex that contains eIF4E that binds the mRNA cap structure, eIF4A, an RNA helicase that prepares the template for ribosome loading, and eIF4G, which provides a scaffold for bridging the mRNA and ribosome pre-initiation complex (reviewed in Lin et al. [41]). MYC stimulates cap-dependent translation through regulation of eIF4E, eIF4A, and eIF4G, while mTORC1 activity also regulates eIF4E. mTORC1-dependent phosphorylation of 4E binding protein-1 (4EBP1), an eIF4E-binding protein, induces the release of eIF4E for translation initiation. Just as backcrossing $E \mu-M Y C$ mice into a ribosomal protein-insufficient background (RPL34+/ - or RPL38+/-) or treating with an mTORC1 inhibitor like rapamycin reduce MYC-initiated tumorigenesis, so too does backcrossing into a non-phosphorylatable 4EBP1 background in which eIF4E remains inhibited [42]. Thus, MYC exerts both a quantitative and a qualitative control over protein translation to drive oncogenesis.

\section{Polyamines}

Polyamines are small organic cations found in nearly all living organisms that are essential for cell growth and survival. The three principal polyamines synthesized by mammals are putrescine, spermidine, and spermine, and these polycations support cell growth and proliferation through cationic, chaperone-like interactions with anionic macromolecules such as DNA, RNA, proteins, and phospholipids. Polyamines also have sequence-dependent DNA interactions and play roles in specific cellular processes such as DNA methylation, chromatin structure, transcription, ion channel function, and scavenging of reactive oxygen species. While their chaperone functions are important for maximizing protein translation efficiency, polyamines also play a direct role in translation by the absolute requirement for spermidine to activate the eukaryotic translation initiation factor 5A (eIF5A) elongation factor and by indirect regulation of $\mathrm{mTORC} 1$ and eIF4E activity. The maintenance of normal intracellular polyamine levels is essential to support cell proliferation [43], and polyamine homeostasis is maintained by a multi-level regulation of their transport, biosynthesis, and catabolism.

\subsection{Polyamine Biosynthesis and Metabolism}

The first, and in most conditions, rate-limiting step in polyamine biosynthesis is the conversion of ornithine (a product of the urea cycle or formed from the catabolism of glutamine) to putrescine catalyzed by ornithine decarboxylase (ODC, encoded by ODC1). Putrescine is then converted to spermidine via spermidine synthase (SRM), and spermidine to spermine by spermine synthase (SMS). The activity of the second major regulatory enzyme in polyamine synthesis, adenosylmethionine decarboxylase (AMD, encoded by $A M D 1)$, provides the aminopropyl groups transferred by SRM and SMS. Both ODC and AMD have the shortest half-lives (10-30 min) of any mammalian enzyme, allowing fine-tuning of polyamine synthesis. Ornithine decarboxylase itself is tightly regulated by transcription, post-transcriptional processing, modified translation efficiency, and altered protein stability, with both antizymes (OAZ1 and OAZ2) and an antizyme inhibitor (AZIN1) contributing [44-48]. Polyamine abundance also negatively feeds back on ODC activity by inducing a +1 ribosomal frameshift that is required to translate functional OAZ1 by reading over a stop codon [49].

Catabolic flux is regulated by the inducible spermidine/spermine-N-acetyltransferase (SAT1) that acetylates higher-order polyamines for export through specific transmembrane solute carriers or for oxidation to lower-order polyamines via polyamine oxidase (PAOX), or by spermine oxidase (SMOX) 
activities, enhancing homeotic control over the repertoire of cellular polyamines [50]. Finally, an as of yet incompletely characterized energy-dependent polyamine transporter imports polyamines from the microenvironment and can function to rescue polyamine synthesis deficits. These pathways are more completely reviewed in Miller-Fleming et. al. [51]. Indeed, the remarkable investment made to regulate polyamine homeostasis underscores the importance of this pathway in mammalian biology.

\subsection{MYC, Polyamines, and Cancer}

Deregulated polyamine metabolism has been implicated in several pathologies, notably cancer. Polyamines are abundant in proliferative tissues, including cancer tissues, and are present at much lower levels in senescent and non-proliferative tissues [52-54]. Neuroblastoma is a highly lethal pediatric malignancy of neural crest cells and a prototypical MYC-driven cancer. MYCN is deregulated through genomic amplification in $\sim 40 \%$ of high-risk neuroblastomas $[9,55]$, while MYC is frequently deregulated in a high proportion of the remainder [56,57]. Additionally, $O D C 1$ itself has been shown to be amplified in $\sim 6 \%$ of high-risk tumors along with $M Y C N$ and associates with exceptionally poor tumor survival $([3,58,59]$ and unpublished data). ODC1 is a direct MYC target and bona fide oncogene [60-62], providing the first demonstration of dual amplification of an oncogenic transcription factor and its oncogenic target gene. Whether this confers an enhanced dependency on polyamines or a resistance mechanism against efforts to deplete polyamines, is under further investigation, since this distinction will inform enrichment strategies for polyamine-depletion cancer trials.

Beyond this somatic activation of polyamine synthesis, transcriptome analyses identified polyamine metabolism as coordinately deregulated by MYC in neuroblastomas. Aggressive tumor behavior and poor outcome is correlated with high expression of synthetic genes (ODC1, SRM, SMS, $A M D 1, A Z I N 1)$ and low expression of catabolic genes (OAZ1, OAZ2, SAT1, PAOX), and these were identified as direct MYC effects by promoter activity and MYCN binding studies ([3]). Many of these correlations retained independent significance in multivariate analyses controlled for key prognostic variables. These data validate polyamine homeostasis as a key oncogenic output of hyperactivated MYC signaling.

\subsection{Polyamines and Protein Translation}

Polyamines are important at both the initiation and elongation stages of mRNA translation, though all of their direct and indirect effects on protein synthesis have yet to be fully elucidated [63]. Studies in fractionated mammalian cell-free translation systems demonstrated that the addition of polyamines stimulated protein translation of diverse mRNA species up to eightfold [64,65]. Spermidine and spermine were more potent in this role than putrescine, and it was noted that some mRNAs appeared particularly dependent on the presence of polyamines for their translation, forming a polyamine modulon [66] or polyamine-dependent translatome.

Polyamines regulate protein translation in cells via effects on translation initiation, by modulation of eIF4F complex activity, and on a specific translation factor, namely, eIF5A. Deficits in these processes likely account for the essential roles of polyamines in cell proliferation [63]. While polyamines function to chaperone other macromolecules, the link between their homeostatic control and protein translation was underscored by studies in which SAT1 was overexpressed via adenoviral transduction in HeLa cells. Acute hyperactivation of SAT1 cells led to a rapid depletion of cellular spermidine and spermine that coincided with abolished global protein synthesis, without a change in DNA or RNA synthesis [67]. Treatment with difluoromethylornithine (DFMO, an inhibitor of ornithine decarboxylase that depletes putrescine and spermidine from cells) also caused a reduction in global protein synthesis in vitro, further underscoring the connection between polyamines and translation [63]. In the Eu-MYC model, treating lymphoma-prone mice with DFMO extended survival [4] to a similar extent as genetic crosses into the RPL24+ / - background [39] or a dominant-negative 4EBP1 mutant background [42], consistent with the notion that the major mechanism downstream of DFMO is disruption of protein translation. 
Newer tools now being employed to define the effects of polyamine perturbation on ribosomes and their activities are leading to more refined insights into these pathways.

\section{Targeting Polyamine Homeostasis and Protein Translation as a Therapy for MYC-Driven Cancers}

MYC-driven malignancies have a significant dependence on the creation of biomass to support cellular proliferation, specifically on the upregulation of genes that support protein synthesis: ribosome biogenesis, tRNAs, and elongation factors (Figure 1). Indeed, in an analysis across $>1000$ cancer cell lines from the Cancer Cell Line Encyclopedia, a bioribogenesis and protein translation gene set score was found to be highly correlated with MYC expression, with a correlation coefficient of 0.48 at $p<0.0001$ [68]. This dependence on enhanced protein synthesis for oncogenicity and the concomitant requirement for polyamines to support protein translation provide therapeutic opportunities. Discussed below are strategies to target polyamine metabolism directly as well as key protein translation factors that are influenced by polyamines, as potential points of therapeutic synergy.

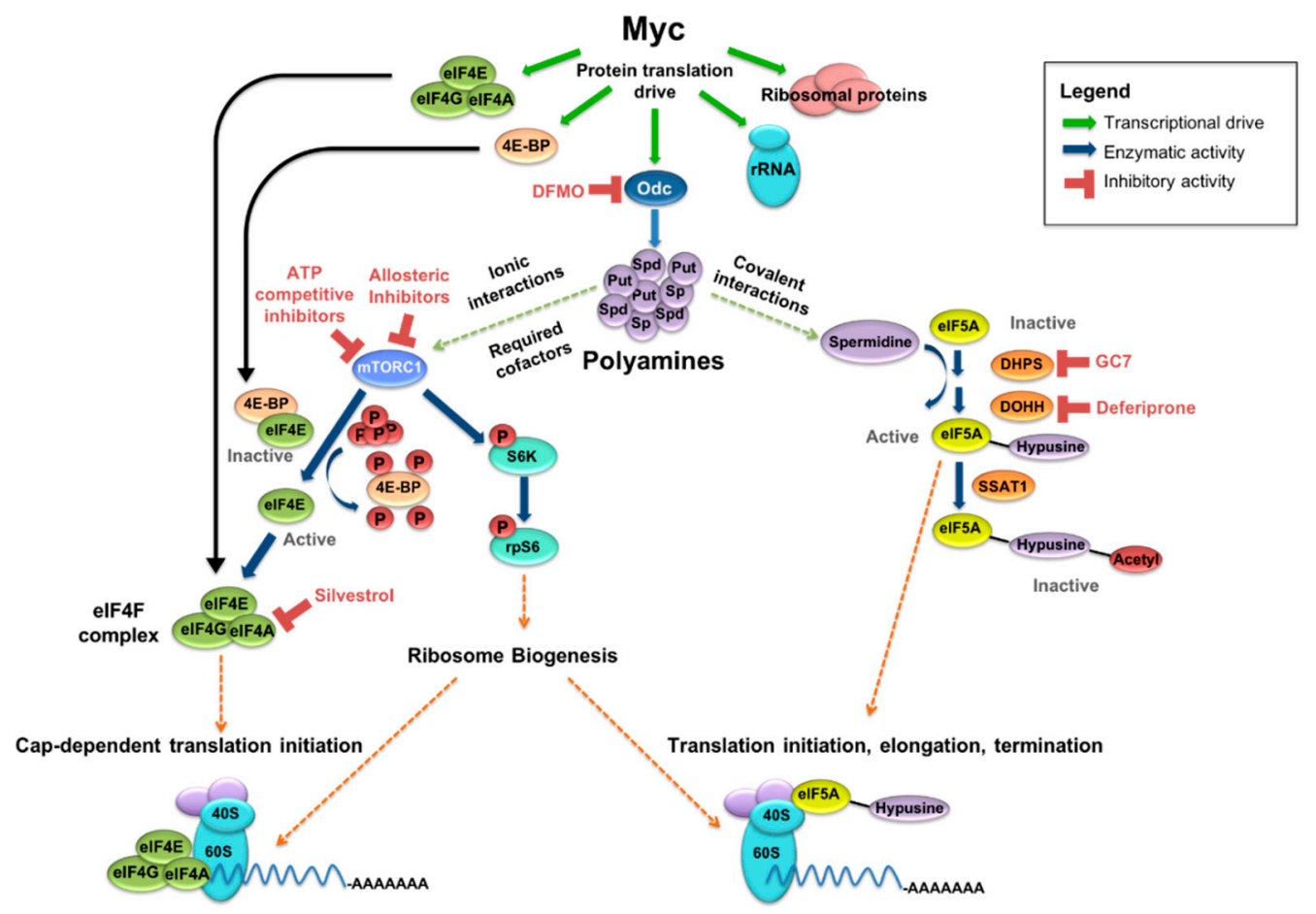

Figure 1. MYC drives protein synthetic output and polyamine metabolism. MYC-driven output includes ribosomal proteins, rRNA, and translation factors, among others. MYC also transcriptionally upregulates ornithine decarboxylase (ODC), a rate-limiting enzyme in polyamine synthesis, as well as spermidine synthase (SRM) and other key polyamine enzymes. Polyamines support protein synthesis in several ways, including spermidine-dependent activation of eukaryotic initiation factor 5A (eIF5A) and as cofactors in the mTORC1-driven release of eIF4E from eIF4E-binding protein 1 (4EBP1) and phosphorylation of S6K. Inhibitors exist for several key enzymes in these polyamine-supported pathways, allowing for the possibility of indirect MYC inhibition through a multi-faceted pharmacologic approach.

\subsection{Targeting Polyamine Homeostasis}

Polyamine metabolism is upregulated in proliferating tissues, including cancers. Increased polyamine production can be inhibited through impairing synthesis, decreasing import, or increasing export. Not surprisingly, compounds affecting each of these facets of polyamine homeostasis, alone or in combination, provide attractive anticancer approaches currently under development. 
DFMO, or eflornithine, is an irreversible inhibitor of ornithine decarboxylase. As a modified ornithine analog, DFMO works through enzyme-activated covalent binding to its target enzyme, ODC. Intravenous DFMO is Food and Drug Administration (FDA)- and European Medicines Agency (EMA)-approved for the treatment of Trypanosomiasis (African sleeping sickness), as ODC activity is essential for the survival of that protozoan, and has also shown anti-cancer activity in a variety of preclinical models $[3,4,69,70]$. DFMO is orally bioavailable and has acceptable tolerability even at high doses, which may be required to inactivate ODC in cells with MYC and /or ODC1 amplification. The mechanisms of DFMO's anti-cancer activity include tumor cell polyamine depletion and impaired protein translation, although this remains an area of ongoing investigation. DFMO alone significantly delayed tumor initiation in neuroblastoma-prone TH-MYCN mice (homozygous for the MYCN transgene), although all mice eventually succumbed to the tumor. More surprisingly, initiating DFMO treatment after tumor onset in this rapidly lethal tumor model also extended survival [69]. In that setting, progressing tumors had reduced putrescine, as evidence of ODC inhibition, but preserved spermidine and spermine because of compensatory mechanisms, like activation of AMD and enhanced polyamine uptake to restore polyamine levels, demonstrating that tumor progression downstream of MYC requires sufficient polyamines.

Adenosylmethionine decarboxylase, a second major regulatory enzyme in the polyamine synthetic pathway, has oncogenic activities in prostate cancer where it is stabilized and activated by mTORC1, showing increased levels in mTORC1-activated tumors and decreased levels in tumors from patients treated with the mTORC1 inhibitor everolimus [71]. Pharmacologic inhibition of AMD is achieved with SAM486, and combining this agent with DFMO to inhibit both rate-limiting polyamine synthetic enzymes in TH-MYCN homozygous mice was able to prevent tumor initiation in $40 \%$ of mice when used pre-emptively, confirming the requirement for polyamine sufficiency downstream of MYC in tumor initiation [69]. However, the same synergistic activity was not seen when DFMO and SAM486 were used to treat established and progressing tumors in this model.

\subsection{Targeting Polyamine Uptake and Export}

Additional efforts to augment polyamine depletion in concert with DFMO therapy include approaches that enhance polyamine export or block uptake mechanisms. Sat1 is the key enzyme regulating the catabolism of the polyamines spermine and spermidine, as this acetyltransferase acetylates them for export from the cell. SAT1 activity can be induced by non-steroidal anti-inflammatory drugs (NSAIDs) such as celecoxib or sulindac, and synergy with DFMO has been shown in preclinical neuroblastoma models where the combination enhanced tumor polyamine depletion and extended survival. More importantly, a randomized, placebo-controlled trial of DFMO in combination with sulindac was shown to markedly reduce the recurrence of adenomas, particularly advanced adenomas, in at-risk adults [2]. Several clinical trials are currently open using DFMO in the treatment of a variety of pre-cancer and cancer states, both alone and in combination with chemotherapeutics and NSAIDs, including in patients with neuroblastoma.

Various polyamine transport inhibitors are being developed for anti-tumor activity in combination with DFMO. AMXT1501 is one such inhibitor that in combination with DFMO has been shown to have anti-tumor and immune stimulatory activities in a mouse model of squamous cell carcinoma [72,73] and also to inhibit neuroblastoma proliferation in vitro [69] and extend survival of TH-MYCN mice with neuroblastoma in vivo. Most recently, the polyamine transport inhibitor Trimer44NMe was used in combination with DFMO in an orthotopic mouse model of pancreatic ductal adenocarcinoma, demonstrating tumor growth inhibition as well as decreased MYC expression [74]. Transport inhibitors in combination with polyamine synthesis inhibition may be a promising pharmacologic strategy for the treatment of polyamine-dependent tumors, as this approach blocks the primary rescue pathway utilized by cancer cells undergoing polyamine deprivation stress.

It is possible that inhibiting more than one aspect of polyamine metabolism may provide an effective strategy for targeting the dependency of malignant tissue having high levels of polyamines. 
Work is ongoing for the transition of several of these polyamine-inhibitory compounds, alone and in various combinations, from a preclinical to clinical setting.

\subsection{The eIF4F Complex and Cap-Dependent Translation}

In addition to synergistically targeting polyamine homeostatic pathways to augment the extent of polyamine depletion, another approach is to look for synergy opportunities in the principal oncogenic pathways disrupted by polyamine depletion. Given the relationship between polyamines and protein translation, this is an area of active investigation.

The eIF4F cap-binding translation initiation complex is responsible for cap-dependent mRNA translation. eIF4F is composed of eF4E (cap-binding protein), eIF4A (ATP-dependent RNA helicase), and eIF4G (scaffolding protein). The formation of the eIF4F complex is highly regulated and dependent on several signaling pathways that are also involved in oncogenesis. eIF4E is the least abundant of the eIF4F complex proteins and therefore is the rate-limiting element in eIF4F formation. 4E-binding proteins sequester eIF4E, and phosphorylation of 4EBP1 by $\mathrm{mTORC} 1$ is required for the release of eIF4E. The central role of eIF4E as a highly regulated component of the eIF4F complex and its overexpression in several cancers make eIF4E an attractive target for the development of therapeutic agents [75]. Overexpression of eIF4E transforms immortalized mouse NIH-3T3 cell [76] and cooperates with the viral homolog of MYC to transform rat embryo fibroblasts [77]. Subsequently, eIF4E was found to cooperate with MYC in the E $\mu-M Y C$ transgenic mouse model to enhance lymphomagenesis and drug resistance in vivo through antagonism of MYC-dependent apoptosis [78,79]. Additionally, induced overexpression of eIF4E leads to the recruitment of ribosomes to a subset of mRNAs that promote oncogenesis, specifically, mRNAs with highly structured 5' untranslated regions (5'UTRs) [80-82]. Of note, mRNAs with highly structured 5'UTRs, that are translated more efficiently in the setting of eIF4E overexpression, include two relevant oncogenes, i.e., ODC1 and MYC [83,84].

Increased MYC expression leads directly to increased transcription of three core components of the eIF4F complex (eIF4E, eIF4AI, and eIF4GI), mediated through canonical E-boxes in their promoters. Enhanced expression of these core components by MYC results in a feed-forward loop with increased eIF4F expression, leading to increased translation of MYC [85]. The polyamine putrescine was found to increase the activation of mTORC1 and the subsequent phosphorylation of 4EBP1, and increasing concentrations of putrescine led to increased protein synthesis and cell proliferation in a dose-dependent fashion. These changes in protein production and proliferation were reversed in the presence of the mTOR inhibitor rapamycin [86]. Further linking mTORC1 with polyamine signaling is its role as an amino acid sensor. Oncogenic polyamine synthesis maintains methionine and s-adenosyl-methionine (SAM) at levels sufficient to inhibit SAMTOR, a nutrient sensor in the mTORC1 pathway, and supports mTORC1 signaling [87]. In the setting of DFMO, there is enhanced AMD activity that leads to reduced pools of methionine and SAM, de-repression of SAMTOR, and inhibition of mTORC1 activation. Additionally, in ODC over-producing cells, there was an increase in eIF4E phosphorylation and subsequent helicase activity of the eIF4F complex [88]. This, in combination with increased efficiency of translation of $O D C 1$ in the setting of eIF4E overexpression, suggests an additional feed-forward loop of the eIF4F components and an oncogene, here ODC1, possibly of relevance to oncogenic transformation.

\subsection{Targeting The eIF4F Complex}

Several agents that inhibit the components of the eIF4F complex have shown preclinical antitumor activity and may have enhanced activity in combination with polyamine depletion agents like DFMO. A 4E-antisense oligonucleotide to reduce the expression of eIF4E was shown to inhibit tumor growth in a prostate cancer xenograft model [89] and was safe in humans in a Phase I clinical trial, though it did not demonstrate anti-tumor activity as a single agent [90]. Pateamine A is a macrolide originally isolated from marine sponges in the 1990s, and an analog of pateamine led to tumor regression in two 
melanoma mouse xenograft models [91]. Inhibitors of eIF4A helicase activity include hippuristanol, pateamine $\mathrm{A}$, and other flavaglines and rocaglates derived from natural products.

Hippuristanol inhibits the binding of mRNA to eIF4A and has been shown to reverse the resistance to chemotherapy and induce apoptosis in synergy with ABT-737 (BCL-2 inhibitor) in the E $\mu-M Y C$ lymphoma model [92]. The most extensively studied of the agents targeting the eIF4A helicase is silvestrol, which belongs to the flavagline class and enhances eIF4A binding to mRNA, thus preventing its participation in the eIF4F complex. This agent extended survival when combined

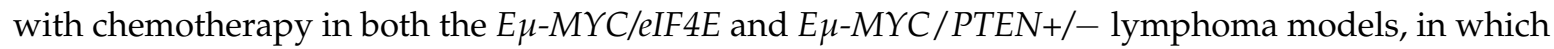
MYC and mTOR are deregulated to drive lymphoma onset [93]. In the NOTCH1-driven murine T-ALL model of acute leukemia, in which MYC is also deregulated [94], silvestrol was found to preferentially inhibit the translation of mRNAs with G-quadruplex structures, which include several transcription factors and epigenetic regulators [95].

\subsection{Eukaryotic Translation Initiation Factor $5 A$ and Its Spermidine-Dependent Activation}

Eukaryotic translation initiation factor $5 \mathrm{~A}$ is a unique RNA-binding protein that is evolutionarily conserved from fungi through plants, insects, and mammals and is essential to eukaryotic cell viability. There are two paralogous genes encoding isoforms of eIF5A: eIF5A1 at chromosome band 17p13 and eIF5A2 at 3q26 [96]. eIF5A1 is ubiquitously expressed, while eIF5A2 expression is largely restricted to the brain and testis. Either isoform can rescue yeast with genetic eIF5A deletion, consistent with their functional redundancy. eIF5A was originally implicated in having stimulatory effects in the formation of the first peptide bond between Met-tRNA and puromycin in translation initiation [97,98]. However, its effects are likely far broader on the basis of polysome analyses demonstrating ribosomal stalling in eIF5A-depleted conditions in yeast $[99,100]$. The bacterial orthologue, elongation factor $P$ (EF-P), is structurally and functionally similar to eIF5A. EF-P was found to be important in resolving ribosomal stalling at sites of consecutive proline residues [101,102], and eIF5A's effect on the resolution of polyproline stretches was subsequently established in yeast [103]. Most recently, eIF5A has been shown to have a role in accelerating peptidyl transfer more generally at ribosome stalling sites, though tripeptide motifs have differential dependence on the activity of this factor (with prolines featuring prominently in disruptive motifs), and to promote peptide release from the ribosome at termination [104]. eIF5A appears to effect multiple facets of protein synthesis, and the biologic and therapeutic implications of its functions remain areas of active investigation. The extent to which eIF5A contributes to global protein translation may also be a function of genome complexity, as proline-rich motifs occur at higher frequency in the proteomes of higher organisms [105].

In addition to roles as cationic chaperones, the polyamine spermidine is absolutely required for the activation of eIF5A [106]. eIF5A undergoes a two-step post-translational modification termed hypusination, in which a butyl amine moiety of spermidine is covalently bound to a lysine residue (K50) of eIF5A to yield its hypusinated form (Figure 1). Hypusination of eIF5A is essential for most, if not all, of its activities, therefore making spermidine an essential substrate for eIF5A activation. The two enzymes necessary for hypusination of eIF5A, i.e., deoxyhypusine synthase (DHS) and deoxyhypusine hydroxylase (DOHH), are dedicated exclusively to this pathway and, like eIF5A, are essential genes [107]. No other eukaryotic protein is known to require hypusination, further underscoring the unique importance of this polyamine-dependent modification [108]. Hypusination of eIF5A occurs co-translationally and appears to be irreversible, suggesting a non-dynamic role in regulating eIF5A activity under normal conditions. Inactivation through acetylation by the SAT1 acetyltransferase may provide additional regulation, though this remains incompletely understood [109]. Indeed, while SAT1 can acetylate the hypusine moiety of eIF5A, rendering the factor inactive, prolonged overexpression of SAT1 in HeLa cells abolished protein translation but inactivated less than $10 \%$ of the total hypusinated-eIF5A pool [67].

Both eIF5A isoforms have been linked to cancer functions, though, given the weak or undetectable expression of eIF5A2 in most tissues, their overexpression in various cancers is more readily identified. 
Moreover, high expression of eIF5A2 has been found in numerous cancer in association with EIF5A2 gene amplification and correlates with advanced cancer stage and worse prognosis for many patients, leading to its identification as an oncogene (reviewed in Nakanishi et al. [110]). However, a targeted shRNA library screen identified EIF5A, AMD1, SRM, and DHS as tumor suppressors in the E $\mu-M Y C$ model [111]. This data has yet to be reconciled with extensive data linking polyamine sufficiency with malignant progression, though it is possible that, in B cells, an eIF5A-dependent translatome includes proteins with tumor suppressor functions disproportionately over those with putative oncogenic roles. Alternatively, there may be functional distinctions between the role of eIF5A in tumor initiation versus maintenance or progression. Indeed, as mentioned, AMD inhibition cooperates with ODC inhibition to block tumor initiation in the neural crest of TH-MYCN neuroblastoma-prone mice, yet it antagonizes DFMO activity in the setting of therapy for established and progressing tumors [69].

\subsection{Inhibition of eIF5A Hypusination}

The key enzymes in activating hypusination of eIF5A at lysine K-50 are DHS and DOHH, both of which have direct inhibitors. N1-Guanyl-1,7-diaminoheptane (GC7) inhibits DHS and has been studied in vitro in a variety of cancer cell lines. Indeed, GC7 treatment augments the activity of a variety of chemotherapeutic agents and has synergy with targeted agents such as imatinib in $B C R-A B L-d r i v e n$ leukemia [112-114]. However, the clinical utility of GC7 beyond in vitro studies is uncertain, as it is a spermidine analog and can therefore affect other aspects of polyamine homeostasis not specific to hypusination of eIF5A. DOHH requires iron for the hydroxylation of hypusine, making $\mathrm{DOHH}$ susceptible to inhibition by iron chelators such as ciclopirox and deferiprone, both of which are clinically available agents. Ciclopirox is an antifungal agent and has been shown to inhibit growth and stimulate apoptosis in a variety of cancer types in vitro [115,116] and in vivo [117]. Deferiprone is an oral chelator used to treat iron overload secondary to chronic blood transfusion in thalassemia and was found to inhibit proliferation of cervical cancer cells in vitro [118]. A Phase I clinical trial in patients with advance hematologic malignancies to assess dose and side effect profile of ciclopirox demonstrated clinical tolerability of escalated doses and even evidence of disease stabilization in a few patients [119]. It is possible that a combination therapy with one of these agents blocking a key step in the hypusination of eIF5A and a polyamine antagonist may show additive or synergistic anti-tumor effects.

\section{Conclusions: Current Gaps and Future Perspective}

MYC-driven bioribogenesis and protein synthesis are central to its oncogenicity. While directly targeting MYC has proven difficult, downstream effectors driving increases in global and selective protein synthesis provide numerous targetable pathways that have potent oncogenic roles and an exploitable therapeutic index. Here, we have highlighted some of these pathways that are essential to the increased protein synthetic drive induced by MYC. Though polyamine homeostasis is essential for normal cell growth and proliferation, an increased drive for polyamine uptake and synthesis noted in human cancers may provide a targetable MYC-driven dependency. Gene expression signatures of MYC-driven cancers often demonstrate increased expression of enzymes involved in polyamine synthesis and decreased expression of polyamine catabolic enzymes, highlighting this coordinated signaling downstream of MYC. Polyamines play an important role in protein synthesis, both globally and selectively, by activating key translation factors such as eIF5A. However, the exact mechanisms by which polyamine depletion leads to protein translation stress and the mechanisms of anti-tumor activity when polyamines are depleted from tumor cells remain the subject of ongoing work.

Current studies in our laboratory and others are aimed at using a combination strategy to induce protein translation stress through direct polyamine depletion in addition to inhibition of the translation machinery in neuroblastoma and other MYC-driven tumor models. Polyamine depletion, alone or in combination with inhibitors of protein translation, may provide a potent stress on a MYC-driven cancer, which may result in clinically significant anti-tumor activity. Such preclinical work is required for the 
informed design of clinical protocols to test these approaches, with the hope of understanding which additional compounds, if any, provide the highest likelihood of clinically relevant anti-tumor effects.

Author Contributions: A.T.F. conceptualized, researched, wrote, and edited the paper. M.D.H. researched, wrote, reviewed, and edited the paper.

Acknowledgments: Support for this review was provided by Alex's Lemonade Stand Foundation (ALSF) Young Investigator Award (ATF), the ALSF Center of Excellence Award (ATF), and the ALSF REACH award (MDH), Hyundai Hope on Wheels Award (MDH), Wipe Out Kids Cancer Award (MDH), and Team Connor Award (MDH).

Conflicts of Interest: The authors declare no conflict of interest. The funding sponsors had no role in the writing of or the decision to publish the manuscript.

\section{References}

1. Igarashi, K.; Kashiwagi, K. Modulation of cellular function by polyamines. Int. J. Biochem. Cell Biol. 2010, 42, 39-51. [CrossRef] [PubMed]

2. Gerner, E.W.; Meyskens, F.L., Jr.; Goldschmid, S.; Lance, P.; Pelot, D. Rationale for, and design of, a clinical trial targeting polyamine metabolism for colon cancer chemoprevention. Amino Acids 2007, 33, 189-195. [CrossRef] [PubMed]

3. Hogarty, M.D.; Norris, M.D.; Davis, K.; Liu, X.; Evageliou, N.F.; Hayes, C.S.; Pawel, B.; Guo, R.; Zhao, H.; Sekyere, E.; et al. ODC1 is a critical determinant of MYCN oncogenesis and a therapeutic target in neuroblastoma. Cancer Res. 2008, 68, 9735-9745. [CrossRef] [PubMed]

4. Nilsson, J.A.; Keller, U.B.; Baudino, T.A.; Yang, C.; Norton, S.; Old, J.A.; Nilsson, L.M.; Neale, G.; Kramer, D.L.; Porter, C.W.; et al. Targeting ornithine decarboxylase in Myc-induced lymphomagenesis prevents tumor formation. Cancer Cell 2005, 7, 433-444. [CrossRef] [PubMed]

5. Thomas, T.; Thomas, T.J. Estradiol control of ornithine decarboxylase mRNA, enzyme activity, and polyamine levels in MCF-7 breast cancer cells: Therapeutic implications. Breast Cancer Res. Treat. 1994, 29, 189-201. [CrossRef] [PubMed]

6. Sheiness, D.K.; Hughes, S.H.; Varmus, H.E.; Stubblefield, E.; Bishop, J.M. The vertebrate homolog of the putative transforming gene of avian myelocytomatosis virus: Characteristics of the DNA locus and its RNA transcript. Virology 1980, 105, 415-424. [CrossRef]

7. Vita, M.; Henriksson, M. The Myc oncoprotein as a therapeutic target for human cancer. Semin. Cancer Biol. 2006, 16, 318-330. [CrossRef] [PubMed]

8. Barrans, S.; Crouch, S.; Smith, A.; Turner, K.; Owen, R.; Patmore, R.; Roman, E.; Jack, A. Rearrangement of MYC is associated with poor prognosis in patients with diffuse large B-cell lymphoma treated in the era of rituximab. J. Clin. Oncol. Off. J. Am. Soc. Clin. Oncol. 2010, 28, 3360-3365. [CrossRef] [PubMed]

9. Brodeur, G.; Seeger, R.; Schwab, M.; Varmus, H.; Bishop, J. Amplification of N-myc in untreated human neuroblastomas correlates with advanced disease stage. Science 1984, 224, 1121-1124. [CrossRef] [PubMed]

10. Chng, W.J.; Huang, G.F.; Chung, T.H.; Ng, S.B.; Gonzalez-Paz, N.; Troska-Price, T.; Mulligan, G.; Chesi, M.; Bergsagel, P.L.; Fonseca, R. Clinical and biological implications of MYC activation: A common difference between MGUS and newly diagnosed multiple myeloma. Leukemia 2011, 25, 1026-1035. [CrossRef] [PubMed]

11. Kanungo, A.; Medeiros, L.J.; Abruzzo, L.V.; Lin, P. Lymphoid neoplasms associated with concurrent t(14;18) and 8q24/c-MYC translocation generally have a poor prognosis. Mod. Pathol. 2006, 19, 25-33. [CrossRef] [PubMed]

12. Wolfer, A.; Wittner, B.S.; Irimia, D.; Flavin, R.J.; Lupien, M.; Gunawardane, R.N.; Meyer, C.A.; Lightcap, E.S.; Tamayo, P.; Mesirov, J.P.; et al. MYC regulation of a "poor-prognosis" metastatic cancer cell state. Proc. Natl. Acad. Sci. USA 2010, 107, 3698-3703. [CrossRef] [PubMed]

13. Bhat, M.; Robichaud, N.; Hulea, L.; Sonenberg, N.; Pelletier, J.; Topisirovic, I. Targeting the translation machinery in cancer. Nat. Rev. Drug Discov. 2015, 14, 261-278. [CrossRef] [PubMed]

14. Truitt, M.L.; Ruggero, D. New frontiers in translational control of the cancer genome. Nat. Rev. Cancer 2016, 16, 288-304. [CrossRef] [PubMed]

15. Gabay, M.; Li, Y.; Felsher, D.W. MYC activation is a hallmark of cancer initiation and maintenance. Cold Spring Harb. Perspect. Med. 2014, 4. [CrossRef] [PubMed]

16. Prochownik, E.V.; Vogt, P.K. Therapeutic targeting of Myc. Genes Cancer 2010, 1, 650-659. [CrossRef] [PubMed] 
17. Casero, R.A., Jr.; Marton, L.J. Targeting polyamine metabolism and function in cancer and other hyperproliferative diseases. Nat. Rev. Drug Discov. 2007, 6, 373-390. [CrossRef] [PubMed]

18. Nesbit, C.E.; Tersak, J.M.; Prochownik, E.V. MYC oncogenes and human neoplastic disease. Oncogene 1999, 18, 3004-3016. [CrossRef] [PubMed]

19. Eilers, M.; Eisenman, R.N. Myc's broad reach. Genes Dev 2008, 22, 2755-2766. [CrossRef] [PubMed]

20. Fernandez, P.C.; Frank, S.R.; Wang, L.; Schroeder, M.; Liu, S.; Greene, J.; Cocito, A.; Amati, B. Genomic targets of the human c-Myc protein. Genes Dev 2003, 17, 1115-1129. [CrossRef] [PubMed]

21. van Riggelen, J.; Yetil, A.; Felsher, D.W. MYC as a regulator of ribosome biogenesis and protein synthesis. Nat. Rev. Cancer 2010, 10, 301-309. [CrossRef] [PubMed]

22. Bouchard, C.; Staller, P.; Eilers, M. Control of cell proliferation by Myc. Trends Cell Biol. 1998, 8, $202-206$. [CrossRef]

23. Mateyak, M.K.; Obaya, A.J.; Adachi, S.; Sedivy, J.M. Phenotypes of c-Myc-deficient rat fibroblasts isolated by targeted homologous recombination. Cell Growth Differ. Mol. Biol. J. Am. Assoc. Cancer Res. 1997, 8, 1039-1048.

24. Adams, J.M.; Harris, A.W.; Pinkert, C.A.; Corcoran, L.M.; Alexander, W.S.; Cory, S.; Palmiter, R.D.; Brinster, R.L. The c-Myc oncogene driven by immunoglobulin enhancers induces lymphoid malignancy in transgenic mice. Nature 1985, 318, 533-538. [CrossRef] [PubMed]

25. Ellwood-Yen, K.; Graeber, T.G.; Wongvipat, J.; Iruela-Arispe, M.L.; Zhang, J.; Matusik, R.; Thomas, G.V.; Sawyers, C.L. Myc-driven murine prostate cancer shares molecular features with human prostate tumors. Cancer Cell 2003, 4, 223-238. [CrossRef]

26. Pelengaris, S.; Littlewood, T.; Khan, M.; Elia, G.; Evan, G. Reversible activation of c-Myc in skin: Induction of a complex neoplastic phenotype by a single oncogenic lesion. Mol. Cell 1999, 3, 565-577. [CrossRef]

27. Weiss, W.A.; Aldape, K.; Mohapatra, G.; Feuerstein, B.G.; Bishop, J.M. Targeted expression of MYCN causes neuroblastoma in transgenic mice. EMBO J. 1997, 16, 2985-2995. [CrossRef] [PubMed]

28. Lin, C.Y.; Loven, J.; Rahl, P.B.; Paranal, R.M.; Burge, C.B.; Bradner, J.E.; Lee, T.I.; Young, R.A. Transcriptional amplification in tumor cells with elevated c-Myc. Cell 2012, 151, 56-67. [CrossRef] [PubMed]

29. Nie, Z.; Hu, G.; Wei, G.; Cui, K.; Yamane, A.; Resch, W.; Wang, R.; Green, D.R.; Tessarollo, L.; Casellas, R.; et al. c-Myc is a universal amplifier of expressed genes in lymphocytes and embryonic stem cells. Cell 2012, 151, 68-79. [CrossRef] [PubMed]

30. Sabo, A.; Kress, T.R.; Pelizzola, M.; de Pretis, S.; Gorski, M.M.; Tesi, A.; Morelli, M.J.; Bora, P.; Doni, M.; Verrecchia, A.; et al. Selective transcriptional regulation by Myc in cellular growth control and lymphomagenesis. Nature 2014, 511, 488-492. [CrossRef] [PubMed]

31. Walz, S.; Lorenzin, F.; Morton, J.; Wiese, K.E.; von Eyss, B.; Herold, S.; Rycak, L.; Dumay-Odelot, H.; Karim, S.; Bartkuhn, M.; et al. Activation and repression by oncogenic MYC shape tumour-specific gene expression profiles. Nature 2014, 511, 483-487. [CrossRef] [PubMed]

32. Mourant, J.R.; Short, K.W.; Carpenter, S.; Kunapareddy, N.; Coburn, L.; Powers, T.M.; Freyer, J.P. Biochemical differences in tumorigenic and nontumorigenic cells measured by Raman and infrared spectroscopy. J. Biomed. Opt. 2005, 10, 031106. [CrossRef] [PubMed]

33. O'Connell, B.C.; Cheung, A.F.; Simkevich, C.P.; Tam, W.; Ren, X.; Mateyak, M.K.; Sedivy, J.M. A large scale genetic analysis of c-Myc-regulated gene expression patterns. J. Biol. Chem. 2003, 278, 12563-12573. [CrossRef] [PubMed]

34. Ji, H.; Wu, G.; Zhan, X.; Nolan, A.; Koh, C.; De Marzo, A.; Doan, H.M.; Fan, J.; Cheadle, C.; Fallahi, M.; et al. Cell-type independent MYC target genes reveal a primordial signature involved in biomass accumulation. PLoS ONE 2011, 6, e26057. [CrossRef] [PubMed]

35. Boon, K.; Caron, H.N.; van Asperen, R.; Valentijn, L.; Hermus, M.C.; van Sluis, P.; Roobeek, I.; Weis, I.; Voute, P.A.; Schwab, M.; et al. N-myc enhances the expression of a large set of genes functioning in ribosome biogenesis and protein synthesis. EMBO J. 2001, 20, 1383-1393. [CrossRef] [PubMed]

36. Chen, Q.R.; Song, Y.K.; Yu, L.R.; Wei, J.S.; Chung, J.Y.; Hewitt, S.M.; Veenstra, T.D.; Khan, J. Global genomic and proteomic analysis identifies biological pathways related to high-risk neuroblastoma. J. Proteome Res. 2010, 9, 373-382. [CrossRef] [PubMed]

37. Ruggero, D. The role of Myc-induced protein synthesis in cancer. Cancer Res. 2009, 69, 8839-8843. [CrossRef] [PubMed] 
38. Wu, C.H.; Sahoo, D.; Arvanitis, C.; Bradon, N.; Dill, D.L.; Felsher, D.W. Combined analysis of murine and human microarrays and ChIP analysis reveals genes associated with the ability of MYC to maintain tumorigenesis. PLoS Genet. 2008, 4, e1000090. [CrossRef] [PubMed]

39. Barna, M.; Pusic, A.; Zollo, O.; Costa, M.; Kondrashov, N.; Rego, E.; Rao, P.H.; Ruggero, D. Suppression of Myc oncogenic activity by ribosomal protein haploinsufficiency. Nature 2008, 456, 971-975. [CrossRef] [PubMed]

40. Pyronnet, S.; Sonenberg, N. Cell-cycle-dependent translational control. Curr. Opin. Genet. Dev. 2001, 11, 13-18. [CrossRef]

41. Lin, C.J.; Malina, A.; Pelletier, J. c-Myc and eIF4F constitute a feedforward loop that regulates cell growth: Implications for anticancer therapy. Cancer Res. 2009, 69, 7491-7494. [CrossRef] [PubMed]

42. Pourdehnad, M.; Truitt, M.L.; Siddiqi, I.N.; Ducker, G.S.; Shokat, K.M.; Ruggero, D. Myc and mTOR converge on a common node in protein synthesis control that confers synthetic lethality in myc-driven cancers. Proc. Natl. Acad. Sci. USA 2013, 110, 11988-11993. [CrossRef] [PubMed]

43. Pegg, A.E. Functions of polyamines in mammals. J. Biol. Chem. 2016, 291, 14904-14912. [CrossRef] [PubMed]

44. Albeck, S.; Dym, O.; Unger, T.; Snapir, Z.; Bercovich, Z.; Kahana, C. Crystallographic and biochemical studies revealing the structural basis for antizyme inhibitor function. Protein Sci. Publ. Protein Soc. 2008, 17, 793-802. [CrossRef] [PubMed]

45. Kurian, L.; Palanimurugan, R.; Godderz, D.; Dohmen, R.J. Polyamine sensing by nascent ornithine decarboxylase antizyme stimulates decoding of its mRNA. Nature 2011, 477, 490-494. [CrossRef] [PubMed]

46. Nowotarski, S.L.; Shantz, L.M. Cytoplasmic accumulation of the RNA-binding protein HuR stabilizes the ornithine decarboxylase transcript in a murine nonmelanoma skin cancer model. J. Biol. Chem. 2010, 285, 31885-31894. [CrossRef] [PubMed]

47. Pegg, A.E. Regulation of ornithine decarboxylase. J. Biol. Chem. 2006, 281, 14529-14532. [CrossRef] [PubMed]

48. Shantz, L.M. Transcriptional and translational control of ornithine decarboxylase during ras transformation. Biochem. J. 2004, 377, 257-264. [CrossRef] [PubMed]

49. Palanimurugan, R.; Scheel, H.; Hofmann, K.; Dohmen, R.J. Polyamines regulate their synthesis by inducing expression and blocking degradation of ODC antizyme. EMBO J. 2004, 23, 4857-4867. [CrossRef] [PubMed]

50. Kramer, D.L.; Diegelman, P.; Jell, J.; Vujcic, S.; Merali, S.; Porter, C.W. Polyamine acetylation modulates polyamine metabolic flux, a prelude to broader metabolic consequences. J. Biol. Chem. 2008, 283, 4241-4251. [CrossRef] [PubMed]

51. Miller-Fleming, L.; Olin-Sandoval, V.; Campbell, K.; Ralser, M. Remaining mysteries of molecular biology: The role of polyamines in the cell. J. Mol. Biol. 2015, 427, 3389-3406. [CrossRef] [PubMed]

52. Evageliou, N.F.; Hogarty, M.D. Disrupting polyamine homeostasis as a therapeutic strategy for neuroblastoma. Clin. Cancer Res. Off. J. Am. Assoc. Cancer Res. 2009, 15, 5956-5961. [CrossRef] [PubMed]

53. Gamble, L.D.; Hogarty, M.D.; Liu, X.; Ziegler, D.S.; Marshall, G.; Norris, M.D.; Haber, M. Polyamine pathway inhibition as a novel therapeutic approach to treating neuroblastoma. Front. Oncol. 2012, 2, 62. [CrossRef] [PubMed]

54. Thomas, T.; Thomas, T.J. Polyamines in cell growth and cell death: Molecular mechanisms and therapeutic applications. Cell. Mol. Life Sci. 2001, 58, 244-258. [CrossRef] [PubMed]

55. Seeger, R.C.; Brodeur, G.M.; Sather, H.; Dalton, A.; Siegel, S.E.; Wong, K.Y.; Hammond, D. Association of multiple copies of the N-myc oncogene with rapid progression of neuroblastomas. New Engl. J. Med. 1985, 313, 1111-1116. [CrossRef] [PubMed]

56. Fredlund, E.; Ringner, M.; Maris, J.M.; Pahlman, S. High Myc pathway activity and low stage of neuronal differentiation associate with poor outcome in neuroblastoma. Proc. Natl. Acad. Sci. USA 2008, 105, 14094-14099. [CrossRef] [PubMed]

57. Westermann, F.; Muth, D.; Benner, A.; Bauer, T.; Henrich, K.O.; Oberthuer, A.; Brors, B.; Beissbarth, T.; Vandesompele, J.; Pattyn, F.; et al. Distinct transcriptional MYCN/c-MYC activities are associated with spontaneous regression or malignant progression in neuroblastomas. Genome Biol. 2008, 9, R150. [CrossRef] [PubMed]

58. Depuydt, P.; Boeva, V.; Hocking, T.D.; Cannoodt, R.; Ambros, I.M.; Ambros, P.F.; Asgharzadeh, S.; Attiyeh, E.F.; Combaret, V.; Defferrari, R.; et al. Genomic amplifications and distal 6q loss: Novel markers for poor survival in high-risk neuroblastoma patients. J. Natl. Cancer Inst. 2018, 110, 1-10. [CrossRef] [PubMed] 
59. George, R.E.; Kenyon, R.; McGuckin, A.G.; Kohl, N.; Kogner, P.; Christiansen, H.; Pearson, A.D.; Lunec, J. Analysis of candidate gene co-amplification with MYCN in neuroblastoma. Eur. J. Cancer 1997, 33, $2037-2042$. [CrossRef]

60. Auvinen, M.; Paasinen, A.; Andersson, L.C.; Holtta, E. Ornithine decarboxylase activity is critical for cell transformation. Nature 1992, 360, 355-358. [CrossRef] [PubMed]

61. Bello-Fernandez, C.; Packham, G.; Cleveland, J.L. The ornithine decarboxylase gene is a transcriptional target of c-Myc. Proc. Natl. Acad. Sci. USA 1993, 90, 7804-7808. [CrossRef] [PubMed]

62. Moshier, J.A.; Dosescu, J.; Skunca, M.; Luk, G.D. Transformation of NIH/3T3 cells by ornithine decarboxylase overexpression. Cancer Res. 1993, 53, 2618-2622. [PubMed]

63. Landau, G.; Bercovich, Z.; Park, M.H.; Kahana, C. The role of polyamines in supporting growth of mammalian cells is mediated through their requirement for translation initiation and elongation. J. Biol. Chem. 2010, 285, 12474-12481. [CrossRef] [PubMed]

64. Atkins, J.F.; Lewis, J.B.; Anderson, C.W.; Gesteland, R.F. Enhanced differential synthesis of proteins in a mammalian cell-free system by addition of polyamines. J. Biol. Chem. 1975, 250, 5688-5695. [PubMed]

65. Igarashi, K.; Hikami, K.; Sugawara, K.; Hirose, S. Effect of polyamines on polypeptide synthesis in rat liver cell-free system. Biochim. Biophys. Acta 1973, 299, 325-330. [CrossRef]

66. Igarashi, K.; Kashiwagi, K. Modulation of protein synthesis by polyamines. IUBMB Life 2015, 67, 160-169. [CrossRef] [PubMed]

67. Mandal, S.; Mandal, A.; Johansson, H.E.; Orjalo, A.V.; Park, M.H. Depletion of cellular polyamines, spermidine and spermine, causes a total arrest in translation and growth in mammalian cells. Proc. Natl. Acad. Sci. USA 2013, 110, 2169-2174. [CrossRef] [PubMed]

68. Manier, S.; Huynh, D.; Shen, Y.J.; Zhou, J.; Yusufzai, T.; Salem, K.Z.; Ebright, R.Y.; Shi, J.; Park, J.; Glavey, S.V.; et al. Inhibiting the oncogenic translation program is an effective therapeutic strategy in multiple myeloma. Sci. Transl. Med. 2017, 9. [CrossRef] [PubMed]

69. Evageliou, N.F.; Haber, M.; Vu, A.; Laetsch, T.W.; Murray, J.; Gamble, L.D.; Cheng, N.C.; Liu, K.; Reese, M.; Corrigan, K.A.; et al. Polyamine antagonist therapies inhibit neuroblastoma initiation and progression. Clin. Cancer Res. Off. J. Am. Assoc. Cancer Res. 2016, 22, 4391-4404. [CrossRef] [PubMed]

70. Rounbehler, R.J.; Li, W.; Hall, M.A.; Yang, C.; Fallahi, M.; Cleveland, J.L. Targeting ornithine decarboxylase impairs development of MYCN-amplified neuroblastoma. Cancer Res. 2009, 69, 547-553. [CrossRef] [PubMed]

71. Zabala-Letona, A.; Arruabarrena-Aristorena, A.; Martin-Martin, N.; Fernandez-Ruiz, S.; Sutherland, J.D.; Clasquin, M.; Tomas-Cortazar, J.; Jimenez, J.; Torres, I.; Quang, P.; et al. mTORC1-dependent AMD1 regulation sustains polyamine metabolism in prostate cancer. Nature 2017, 547, 109-113. [CrossRef] [PubMed]

72. Samal, K.; Zhao, P.; Kendzicky, A.; Yco, L.P.; McClung, H.; Gerner, E.; Burns, M.; Bachmann, A.S.; Sholler, G. AMXT-1501, a novel polyamine transport inhibitor, synergizes with DFMO in inhibiting neuroblastoma cell proliferation by targeting both ornithine decarboxylase and polyamine transport. Int. J. Cancer 2013, 133, 1323-1333. [CrossRef] [PubMed]

73. Hayes, C.S.; Shicora, A.C.; Keough, M.P.; Snook, A.E.; Burns, M.R.; Gilmour, S.K. Polyamine-blocking therapy reverses immunosuppression in the tumor microenvironment. Cancer Immunol. Res. 2014, 2, $274-285$. [CrossRef] [PubMed]

74. Gitto, S.B.; Pandey, V.; Oyer, J.L.; Copik, A.J.; Hogan, F.C.; Phanstiel, O.; Altomare, D.A. Difluoromethylornithine combined with a polyamine transport inhibitor is effective against gemcitabine resistant pancreatic cancer. Mol. Pharm. 2018, 15, 369-376. [CrossRef] [PubMed]

75. Malka-Mahieu, H.; Newman, M.; Desaubry, L.; Robert, C.; Vagner, S. Molecular pathways: The eIF4F translation initiation complex-new opportunities for cancer treatment. Clin. Cancer Res. Off. J. Am. Assoc. Cancer Res. 2017, 23, 21-25. [CrossRef] [PubMed]

76. Lazaris-Karatzas, A.; Montine, K.S.; Sonenberg, N. Malignant transformation by a eukaryotic initiation factor subunit that binds to mRNA $5^{\prime}$ cap. Nature 1990, 345, 544-547. [CrossRef] [PubMed]

77. Lazaris-Karatzas, A.; Sonenberg, N. The mRNA 5' cap-binding protein, eIF-4E, cooperates with v-myc or E1A in the transformation of primary rodent fibroblasts. Mol. Cell. Biol. 1992, 12, 1234-1238. [CrossRef] [PubMed] 
78. Ruggero, D.; Montanaro, L.; Ma, L.; Xu, W.; Londei, P.; Cordon-Cardo, C.; Pandolfi, P.P. The translation factor eIF-4E promotes tumor formation and cooperates with c-Myc in lymphomagenesis. Nat. Med. 2004, 10, 484-486. [CrossRef] [PubMed]

79. Wendel, H.G.; De Stanchina, E.; Fridman, J.S.; Malina, A.; Ray, S.; Kogan, S.; Cordon-Cardo, C.; Pelletier, J.; Lowe, S.W. Survival signalling by Akt and eIF4E in oncogenesis and cancer therapy. Nature 2004, 428, 332-337. [CrossRef] [PubMed]

80. Koromilas, A.E.; Lazaris-Karatzas, A.; Sonenberg, N. Mrnas containing extensive secondary structure in their $5^{\prime}$ non-coding region translate efficiently in cells overexpressing initiation factor eIF-4E. EMBO J. 1992, 11, 4153-4158. [PubMed]

81. Larsson, O.; Li, S.; Issaenko, O.A.; Avdulov, S.; Peterson, M.; Smith, K.; Bitterman, P.B.; Polunovsky, V.A. Eukaryotic translation initiation factor $4 \mathrm{E}$ induced progression of primary human mammary epithelial cells along the cancer pathway is associated with targeted translational deregulation of oncogenic drivers and inhibitors. Cancer Res. 2007, 67, 6814-6824. [CrossRef] [PubMed]

82. Smith, M.R.; Jaramillo, M.; Liu, Y.L.; Dever, T.E.; Merrick, W.C.; Kung, H.F.; Sonenberg, N. Translation initiation factors induce DNA synthesis and transform NIH 3 T3 cells. New Biol. 1990, 2, 648-654. [PubMed]

83. De Benedetti, A.; Graff, J.R. eIF-4E expression and its role in malignancies and metastases. Oncogene 2004, 23, 3189-3199. [CrossRef] [PubMed]

84. Shantz, L.M.; Coleman, C.S.; Pegg, A.E. Expression of an ornithine decarboxylase dominant-negative mutant reverses eukaryotic initiation factor 4E-induced cell transformation. Cancer Res. 1996, 56, 5136-5140. [PubMed]

85. Lin, C.J.; Cencic, R.; Mills, J.R.; Robert, F.; Pelletier, J. c-Myc and eIF4F are components of a feedforward loop that links transcription and translation. Cancer Res. 2008, 68, 5326-5334. [CrossRef] [PubMed]

86. Kong, X.; Wang, X.; Yin, Y.; Li, X.; Gao, H.; Bazer, F.W.; Wu, G. Putrescine stimulates the mTOR signaling pathway and protein synthesis in porcine trophectoderm cells. Biol. Reprod. 2014, 91, 106. [CrossRef] [PubMed]

87. Gu, X.; Orozco, J.M.; Saxton, R.A.; Condon, K.J.; Liu, G.Y.; Krawczyk, P.A.; Scaria, S.M.; Harper, J.W.; Gygi, S.P.; Sabatini, D.M. SAMTOR is an S-adenosylmethionine sensor for the mTORC1 pathway. Science 2017, 358, 813-818. [CrossRef] [PubMed]

88. Shimogori, T.; Suzuki, T.; Kashiwagi, K.; Kakinuma, Y.; Igarashi, K. Enhancement of helicase activity and increase of eIF-4E phosphorylation in ornithine decarboxylase-overproducing cells. Biochem. Biophys. Res. Commun. 1996, 222, 748-752. [CrossRef] [PubMed]

89. Graff, J.R.; Konicek, B.W.; Vincent, T.M.; Lynch, R.L.; Monteith, D.; Weir, S.N.; Schwier, P.; Capen, A.; Goode, R.L.; Dowless, M.S.; et al. Therapeutic suppression of translation initiation factor eIF4E expression reduces tumor growth without toxicity. J. Clin. Investig. 2007, 117, 2638-2648. [CrossRef] [PubMed]

90. Hong, D.S.; Kurzrock, R.; Oh, Y.; Wheler, J.; Naing, A.; Brail, L.; Callies, S.; Andre, V.; Kadam, S.K.; Nasir, A.; et al. A phase 1 dose escalation, pharmacokinetic, and pharmacodynamic evaluation of eIF-4E antisense oligonucleotide LY2275796 in patients with advanced cancer. Clin. Cancer Res. Off. J. Am. Assoc. Cancer Res. 2011, 17, 6582-6591. [CrossRef] [PubMed]

91. Kuznetsov, G.; Xu, Q.; Rudolph-Owen, L.; Tendyke, K.; Liu, J.; Towle, M.; Zhao, N.; Marsh, J.; Agoulnik, S.; Twine, N.; et al. Potent in vitro and in vivo anticancer activities of des-methyl, des-amino pateamine A, a synthetic analogue of marine natural product pateamine A. Mol. Cancer Ther. 2009, 8, 1250-1260. [CrossRef] [PubMed]

92. Cencic, R.; Robert, F.; Galicia-Vazquez, G.; Malina, A.; Ravindar, K.; Somaiah, R.; Pierre, P.; Tanaka, J.; Deslongchamps, P.; Pelletier, J. Modifying chemotherapy response by targeted inhibition of eukaryotic initiation factor 4A. Blood Cancer J. 2013, 3, e128. [CrossRef] [PubMed]

93. Bordeleau, M.E.; Robert, F.; Gerard, B.; Lindqvist, L.; Chen, S.M.; Wendel, H.G.; Brem, B.; Greger, H.; Lowe, S.W.; Porco, J.A.; et al. Therapeutic suppression of translation initiation modulates chemosensitivity in a mouse lymphoma model. J. Clin. Investig. 2008, 118, 2651-2660. [CrossRef] [PubMed]

94. Palomero, T.; Lim, W.K.; Odom, D.T.; Sulis, M.L.; Real, P.J.; Margolin, A.; Barnes, K.C.; O’Neil, J.; Neuberg, D.; Weng, A.P.; et al. NOTCH1 directly regulates c-MYC and activates a feed-forward-loop transcriptional network promoting leukemic cell growth. Proc. Natl. Acad. Sci. USA 2006, 103, 18261-18266. [CrossRef] [PubMed] 
95. Wolfe, A.L.; Singh, K.; Zhong, Y.; Drewe, P.; Rajasekhar, V.K.; Sanghvi, V.R.; Mavrakis, K.J.; Jiang, M.; Roderick, J.E.; Van der Meulen, J.; et al. RNA G-quadruplexes cause eIF4A-dependent oncogene translation in cancer. Nature 2014, 513, 65-70. [CrossRef] [PubMed]

96. Jenkins, Z.A.; Haag, P.G.; Johansson, H.E. Human eIF5A2 on chromosome 3q25-q27 is a phylogenetically conserved vertebrate variant of eukaryotic translation initiation factor $5 \mathrm{~A}$ with tissue-specific expression. Genomics 2001, 71, 101-109. [CrossRef] [PubMed]

97. Benne, R.; Hershey, J.W. The mechanism of action of protein synthesis initiation factors from rabbit reticulocytes. J. Biol. Chem. 1978, 253, 3078-3087. [PubMed]

98. Schreier, M.H.; Erni, B.; Staehelin, T. Initiation of mammalian protein synthesis. I. Purification and characterization of seven initiation factors. J. Mol. Biol. 1977, 116, 727-753. [CrossRef]

99. Henderson, A.; Hershey, J.W. Eukaryotic translation initiation factor (eIF) 5A stimulates protein synthesis in saccharomyces cerevisiae. Proc. Natl. Acad. Sci. USA 2011, 108, 6415-6419. [CrossRef] [PubMed]

100. Saini, P.; Eyler, D.E.; Green, R.; Dever, T.E. Hypusine-containing protein eIF5A promotes translation elongation. Nature 2009, 459, 118-121. [CrossRef] [PubMed]

101. Doerfel, L.K.; Wohlgemuth, I.; Kothe, C.; Peske, F.; Urlaub, H.; Rodnina, M.V. Ef-p is essential for rapid synthesis of proteins containing consecutive proline residues. Science 2013, 339, 85-88. [CrossRef] [PubMed]

102. Ude, S.; Lassak, J.; Starosta, A.L.; Kraxenberger, T.; Wilson, D.N.; Jung, K. Translation elongation factor EF-P alleviates ribosome stalling at polyproline stretches. Science 2013, 339, 82-85. [CrossRef] [PubMed]

103. Gutierrez, E.; Shin, B.S.; Woolstenhulme, C.J.; Kim, J.R.; Saini, P.; Buskirk, A.R.; Dever, T.E. eIF5A promotes translation of polyproline motifs. Mol. Cell 2013, 51, 35-45. [CrossRef] [PubMed]

104. Schuller, A.P.; Wu, C.C.; Dever, T.E.; Buskirk, A.R.; Green, R. eIF5A functions globally in translation elongation and termination. Mol. Cell 2017, 66, 194-205. [CrossRef] [PubMed]

105. Mandal, A.; Mandal, S.; Park, M.H. Genome-wide analyses and functional classification of proline repeat-rich proteins: Potential role of eIF5A in eukaryotic evolution. PLoS ONE 2014, 9, e111800. [CrossRef] [PubMed]

106. Wolff, E.C.; Kang, K.R.; Kim, Y.S.; Park, M.H. Posttranslational synthesis of hypusine: Evolutionary progression and specificity of the hypusine modification. Amino Acids 2007, 33, 341-350. [CrossRef] [PubMed]

107. Pallmann, N.; Braig, M.; Sievert, H.; Preukschas, M.; Hermans-Borgmeyer, I.; Schweizer, M.; Nagel, C.H.; Neumann, M.; Wild, P.; Haralambieva, E.; et al. Biological relevance and therapeutic potential of the hypusine modification system. J. Biol. Chem. 2015, 290, 18343-18360. [CrossRef] [PubMed]

108. Cooper, H.L.; Park, M.H.; Folk, J.E.; Safer, B.; Braverman, R. Identification of the hypusine-containing protein hy+ as translation initiation factor eIF-4D. Proc. Natl. Acad. Sci. USA 1983, 80, 1854-1857. [CrossRef] [PubMed]

109. Lee, S.B.; Park, J.H.; Folk, J.E.; Deck, J.A.; Pegg, A.E.; Sokabe, M.; Fraser, C.S.; Park, M.H. Inactivation of eukaryotic initiation factor $5 \mathrm{~A}$ (eIF5A) by specific acetylation of its hypusine residue by spermidine/spermine acetyltransferase 1 (SSAT1). Biochem. J. 2011, 433, 205-213. [CrossRef] [PubMed]

110. Nakanishi, S.; Cleveland, J.L. Targeting the polyamine-hypusine circuit for the prevention and treatment of cancer. Amino Acids 2016, 48, 2353-2362. [CrossRef] [PubMed]

111. Scuoppo, C.; Miething, C.; Lindqvist, L.; Reyes, J.; Ruse, C.; Appelmann, I.; Yoon, S.; Krasnitz, A.; Teruya-Feldstein, J.; Pappin, D.; et al. A tumour suppressor network relying on the polyamine-hypusine axis. Nature 2012, 487, 244-248. [CrossRef] [PubMed]

112. Balabanov, S.; Gontarewicz, A.; Ziegler, P.; Hartmann, U.; Kammer, W.; Copland, M.; Brassat, U.; Priemer, M.; Hauber, I.; Wilhelm, T.; et al. Hypusination of eukaryotic initiation factor 5A (eIF5A): A novel therapeutic target in BCR-ABL-positive leukemias identified by a proteomics approach. Blood 2007, 109, 1701-1711. [CrossRef] [PubMed]

113. Preukschas, M.; Hagel, C.; Schulte, A.; Weber, K.; Lamszus, K.; Sievert, H.; Pallmann, N.; Bokemeyer, C.; Hauber, J.; Braig, M.; et al. Expression of eukaryotic initiation factor 5A and hypusine forming enzymes in glioblastoma patient samples: Implications for new targeted therapies. PLoS ONE 2012, 7, e43468. [CrossRef] [PubMed]

114. Xu, G.; Yu, H.; Shi, X.; Sun, L.; Zhou, Q.; Zheng, D.; Shi, H.; Li, N.; Zhang, X.; Shao, G. Cisplatin sensitivity is enhanced in non-small cell lung cancer cells by regulating epithelial-mesenchymal transition through inhibition of eukaryotic translation initiation factor 5A2. BMC Pulm. Med. 2014, 14, 174. [CrossRef] [PubMed]

115. Zhou, H.; Shen, T.; Luo, Y.; Liu, L.; Chen, W.; Xu, B.; Han, X.; Pang, J.; Rivera, C.A.; Huang, S. The antitumor activity of the fungicide ciclopirox. Int. J. Cancer 2010, 127, 2467-2477. [CrossRef] [PubMed] 
116. Eberhard, Y.; McDermott, S.P.; Wang, X.; Gronda, M.; Venugopal, A.; Wood, T.E.; Hurren, R.; Datti, A.; Batey, R.A.; Wrana, J.; et al. Chelation of intracellular iron with the antifungal agent ciclopirox olamine induces cell death in leukemia and myeloma cells. Blood 2009, 114, 3064-3073. [CrossRef] [PubMed]

117. Kim, Y.; Schmidt, M.; Endo, T.; Lu, D.; Carson, D.; Schmidt-Wolf, I.G. Targeting the wnt/beta-catenin pathway with the antifungal agent ciclopirox olamine in a murine myeloma model. In Vivo 2011, 25, 887-893. [PubMed]

118. Memin, E.; Hoque, M.; Jain, M.R.; Heller, D.S.; Li, H.; Cracchiolo, B.; Hanauske-Abel, H.M.; Pe'ery, T.; Mathews, M.B. Blocking eIF5A modification in cervical cancer cells alters the expression of cancer-related genes and suppresses cell proliferation. Cancer Res. 2014, 74, 552-562. [CrossRef] [PubMed]

119. Minden, M.D.; Hogge, D.E.; Weir, S.J.; Kasper, J.; Webster, D.A.; Patton, L.; Jitkova, Y.; Hurren, R.; Gronda, M.; Goard, C.A.; et al. Oral ciclopirox olamine displays biological activity in a phase i study in patients with advanced hematologic malignancies. Am. J. Hematol. 2014, 89, 363-368. [CrossRef] [PubMed]

(C) 2018 by the authors. Licensee MDPI, Basel, Switzerland. This article is an open access article distributed under the terms and conditions of the Creative Commons Attribution (CC BY) license (http:/ / creativecommons.org/licenses/by/4.0/). 